\title{
Peran Brand Awereness Terhadap Keputusan Pembelian Produk
}

\begin{tabular}{|c|c|c|}
\hline INFO ARTIKEL & \multicolumn{2}{|l|}{ Abstract } \\
\hline $\begin{array}{l}\text { Sejarah Artikel: } \\
\text { Diterima : } \\
\text { Diperbaiki : } \\
\text { Disetujui : } \\
\text { Keywords: } \\
\text { Brand Awareness and Purchasing } \\
\text { Decision }\end{array}$ & \multicolumn{2}{|c|}{$\begin{array}{l}\text { At this time, market competition in the world is very free. This also requires } \\
\text { businesses to be more creative and compete with each other in selling and } \\
\text { marketing their products. Companies must create what strategies are most } \\
\text { effective and efficient to maintain the products offered to be used by consumers } \\
\text { in a sustainable manner. Then we need Brand awareness (brand awareness) } \\
\text { that must be owned by every consumer. Brand awareness is brand awareness } \\
\text { is the ability of a prospective buyer to recognize or recall that a brand is part of } \\
\text { a particular product category. The purpose of this research is to know the role } \\
\text { of brand awareness on consumer purchasing decisions. }\end{array}$} \\
\hline & \multicolumn{2}{|c|}{ Abstraks } \\
\hline $\begin{array}{l}\text { Kata Kunci: } \\
\text { Brand awareness, Keputusan } \\
\text { Pembelian. } \\
\text { DOI: }\end{array}$ & \multicolumn{2}{|c|}{$\begin{array}{l}\text { Pada saat ini, persaingan pasar di dunia sangatlah bebas. Hal ini pula } \\
\text { yang menuntut pelaku usaha untuk lebih kreatif dan saling bersaing } \\
\text { dalam menjual juga memasarkan produknya. Perusahaan harus } \\
\text { menciptakan strategi-strategi apa saja yang paling efektif dan efisien } \\
\text { untuk mempertahankan produk yang ditawarkan agar digunakan oleh } \\
\text { konsumen secara berkelanjutan. Maka perlu adanya Brand awereness } \\
\text { (kesadaran merek) yang harus dimiliki oleh setiap konsumen. Brand } \\
\text { awereness adalah Kesadaran merek (brand awareness) adalah } \\
\text { kesanggupan seorang calon pembeli untuk mengenali atau mengingat } \\
\text { kembali bahwa suatu merek merupakan bagian dari kategori produk } \\
\text { tertentu. Tujuan dari penelitian mengetahui peran brand awereness } \\
\text { terhadap keputusan pembelian konsumen. }\end{array}$} \\
\hline \multicolumn{2}{|c|}{$\begin{array}{l}\text { Koresponsi: } \\
\text { Nama: Firda Ramadayanti } \\
\text { Email: firdaram123@gmail.com p-ISSN: 2598-7763 }\end{array}$} & $\begin{array}{l}\text { ISSN: 2355-9643 (Print) } \\
\text { ISSN: 2460-3775 (on-line) }\end{array}$ \\
\hline
\end{tabular}

\section{PENDAHULUAN}

Industri periklanan merupakan industri yang paling berpengaruh dibidang pemasaran. Iklan adalah alat yang berpengaruh yang dapat menyakinkan pelanggan dan menyampaikan informasi ke pasar. Pertumbuhan industri periklanan Indonesia dalam sewindu terakhir, terhitung menakjubkan. Jika pada tahun 2008, total belanja iklan hanya mencapai Rp 41 triliun, maka di tahun 2014, angka itu tersulap naik lebih dari 3x lipat, menjadi Rp 150 triliun.*) Pertumbuhan bisnis yang luar biasa ini tentunya membuka peluangpeluang baru bagi para pelaku bisnis. Era kompetisi di pasar semakin bertambah, karenanya organisasi atau perusahaan harus memprioritaskan dan memfokuskan kembali upaya pada strategi pemasaran yang bernilai tambah. Berkembangnya teknologi juga mempengaruhi banyaknya informasi yang kita dapat tentang sebuah produk dan membuat semakin banyak dari calon konsumen mencari informasi yang dibutuhkan pada suatu produk sebelum akhirnya diputuskan untuk membeli. Menurut Kotler (2002), keputusan pembelian adalah tindakan dari konsumen untuk mau membeli atau tidak terhadap produk. Dari berbagai faktor yang mempengaruhi konsumen dalam melakukan pembelian suatu produk atau jasa, biasanya konsumen selalu 
mempertimbangkan kualitas, harga dan produk sudah yang sudah dikenal oleh masyarakat Didalam produk tentunya ada atribut produk. Atribut yang paling dipandang salah satunya adalah merek. Merek dipakai identitas dari suatu produk baik barang maupun jasa yang dimiliki untuk membedakan dengan produk lainnya. Merek dapat memberikan manfaat yang besar bagi produsen maupun konsumen. Bagi konsumen merek mampu menambah nilai bagi konsumen. Dimana adanya persepsi dan keyakinan atas produk yang menyebabkan konsumen ingin terasosiasikan dan membelinya, sehingga konsumen tidak segan membayar mahal untuk mendapatkan produk dengan merek tertentu. Konsumen bersedia membayar lebih tinggi suatu produk karena terdapat merek yang merupakan jaminan konsistensi kualitas dan nilai tertentu yang diyakini terkandung didalamnya, tanpa adanya merek konsumen menjadi kurang merasa aman dari kemungkinan buruk diluar harapan.

Brand atau merek yang baik akan menempatkan perusahaannya / produk diatas para competitor lainnya dan membuat menjadi pilihan utama. Pada dasarnya brand akan menjadi kepribadian, karakter dan jiwa perusahaan. Pesatnya persaingan memungkinkan melakukan promosi besar-besaran dengan mengandalkan merek yang mereka punya. Semakin intens promosi yang dilakukan melalui media social, akan mendukung dalam meningkatnya brand awareness dari sebuah produk (Schivinski \& Dabrowski, 2015). . Sebelum konsumen melakukan keputusan pembelian, konsumen harus mengetahui beberapa merek yang terdapat di pasaran. Oleh karena itu konsumen harus mengetahui tentang brand awareness (kesadaran merek). Kesadaran merek (brand awareness) adalah kesanggupan seorang calon pembeli untuk mengenali atau mengingat kembali bahwa suatu merek merupakan bagian dari kategori produk tertentu (Humdiana, 2005). Brand Awareness berpengaruh positif terhadap keputusan pembelian suatu produk baik barang maupun jasa (Akbarsyah, 2012). Pentingnya mempunyai brand awareness yang kuat merupakan kunci bagi perusahaan agar bisa unggul dalam persaingan bisnis. Pasalnya, konsumen cenderung memilih produk atau jasa dari brand yang dikenalnya dan inilah yang membuat penjualan semakin meningkat. Tetapi pada faktanya kadangkala konsumen juga lebih tertarik kepada brand atau merek produk yang singkatnya baru muncul. Mereka cenderung beralih merek karena penasaran dan ingin membandingkan kualitas serta kuantitasnya. Maka kesadaran pada sebuah merek memegang peranan penting dalam keputusan pembelian konsumen. Dalam hal ini konsumen percaya bahwa merek yang mempunyai citra positif merupakan suatu jaminan akan kualitas produk. Konsumen akan selalu membeli produk untuk memenuhi kebutuhan akan tetapi produk mana yang mereka beli dan bagaimana mereka membuat keputusan akan erat hubungannya dengan perasaan mereka terhadap merek-merek yang ditawarkan (Akbarsyah, 2012). Dengan demikian, artikel ini bertujuan untuk mengetahui peran brand awareness terhadap keputusan pembelian.

Tujuan penelitian

1. Untuk mengetahui peran brand awereness dapat mempengaruhi keputusan pembelian.

2. Untuk mengetahui cara meningkatkan brand awereness dimata konsumen.

3. Untuk mengetahui keunggulan memiliki brand awereness dalam perusahaan.

Pemasaran dan Manajemen Pemasaran.

Sunarto (2006: 7) menyatakan bahwa pemasaran adalah proses social yang didalamnya individu dan kelompok mendapatkan apa yang dibutuhkan dan diinginkan dengan menciptakan, menawarkan, dan mempertukarkan produk yangbernilai dengan pihak lain. American Marketing Association (AMA) mendefinisikan manajemen pemasaran sebagai berikut: "Manajemen pemasaran sebagai seni dan ilmu memilih pasar sasaran dan mendapatkan, menjaga, dan menumbuhkan pelanggan dengan menciptakan, menyerahkan, dan mengomunikasikan nilai pelanggan yang unggul". Menurut definisi di atas, dapat dikatakan bahwa manajemen pemasaran merupakan suatu proses yang dimulai dari proses perencanaan, pengarahan, dan pengendalian produk atau jasa, penetapan harga, distribusi, dan promosinya dengan tujuan membantu organisasi dalam mencapai sasarannya. Definisi pemasaran menurut Kotler dan Keller (2013:27) adalah fungsi organisasi dan serangkaian proses untuk menciptakan, mengkomunikasikan, dan menghantarkan nilai kepada pelanggan dan untuk mengelola hubungan pelanggan dengan cara yang menguntungkan organisasi dan pemegang kepentingan. Manajemen pemasaran sebagai seni dan ilmu memilih pasar sasaran dan mendapatkan, menjaga, dan menumbuhkan pelanggan dengan menciptakan, menyerahkan, dan mengkomunikasikan nilai pelanggan yang unggul.

Menurut Kotler (2015:146) pengertian 
manajemen pemasaran adalah sebagai berikut: Manajemen Pemasaran adalah penganalisaan, pelaksanaan, dan pengawasan, program-program yang ditujukan utuk mengadakan pertukaran dengan pasar yang dituju dengan maksud untuk mencapai tujuan organisasi. Hal ini sangat tergantung pada penawaran organisasi dalam memenuhi kebutuhan dan keinginan pasar tersebut serta menentukan harga, mengadakan komunikasi, dan distribusi yang efektif untuk memberitahu, mendorong serta melayani pasar. Menurut Hasan (2013:4) menyatakan bahwa manajemen pemasaran adalah proses mengidentifikasi, menciptakan dan mengkomunikasikan nilai, serta memelihara hubungan yang memuaskan pelanggan untuk memaksimalkan keuntungan perusahaan. Jadi manajemen pemasaran adalah proses analisis, perencanaan, penerapan, dan pengendalian program - program yang dirancang perusahaan untuk menciptakan, membangun, dan mempertahankan pertukaran dengan pasar yang dituju untuk memuaskan pelanggan dan memaksimalkan keuntungan perusahaan.

\section{Brand/Merek.}

Menurut KBBI, merek diatikan sebagai tanda yang dikenakan oleh pengusaha (pabrik, produsen, dan sebagainya) pada barang yang dihasilkan sebagai tanda pengenal; cap (tanda) yang menjadi pengenal untuk menyatakan nama dan sebagainya. Menurut UU merek No 15 Tahun 2001 pasal 1 ayat 1, merek tanda yang berupa gambar, nama, kata, huruf-huruf, angka-angka, susunan warna, atau kombinasi dari unsur-unsur tersebut yang memiliki daya pembeda dan digunakan dalam kegiatan perdagangan. Menurut Jerry McLaughlin yang merupakan co-founder dan CEO pada Branders.com (DeMers, 2013) , brand adalah persepsi yang dipegang seseorang terhadap Anda, sebuah produk, jasa, maupun suatu organisasi, penyebab atau suatu ide. Penciptaan brand merupakan suatu kesengajaan dan usaha yang trampil dalam usaha menciptakan persepsi yang diinginkan orang lain.

Merek juga dibagi dalam pengertian lainnya (Rangkuti, 2013:2), seperti:

a. Brand name (nama merek) yang merupakan bagian yang dapat di ucapkan misalnya, Pepsoden, BMW, Toyota, dan sebagainya.

b. Brand mark (tanda merek) yang merupakan bagian dari merek yang dapat dikenali namun tidak dapat di ucapkan, seperti lambang, desain huruf atau warna khusus.

c. Trade mark (tanda merek dagang) yang merupakan merek atau sebagian merek yang dilindungi hukum karena kemampuannya untuk menghasilkan sesuatu yang istimewa. Tanda dagang ini melindungi penjual untuk menggunakan nama merek (tanda merek).

d. Copyright (hak cipta) yang merupakan hak istimewa yang dilindungi oleh undang-undang untuk memproduksi, menerbitkan dan menjual karya tulis, karya musik, ataupun karya seni.

Brand awareness dapat diartikan dengan bagai-mana sebuah brand bisa muncul pada benak konsumen. Selain itu sebuah brand awareness merupakan kunci bagi sebuah brand untuk dapat berada pada posisi brand equity. Sebuah brand awareness dapat dicerminkan dengan bagaimana pengetahuan dan ciri khas dari sebuah brand di pikiran konsumen (David Aaker 1996; p. 330).

Kesadaran merek menurut Keller (2008) terdiri daribeberapa indikator, yaitu:

1. Konsumen paham seperti apa merek itu

2. Dapat mengenali merek diantara merek pesaing

3. Sadar akan keberadaan merek

4. Konsumen membayangkan ciri merek dengan cepat

5. Konsumen cepat mengenali logo atau simbol merek

Brand awereness

Menurut Hermawan (2014 : 57). Kesadaran merek adalah kemampuan dari seseorang calon

pembeli (potential buyer) untuk mengenali (recognize) atau mengingat (recall) suatu merek yang

merupakan bagian dari suatu kategori produk

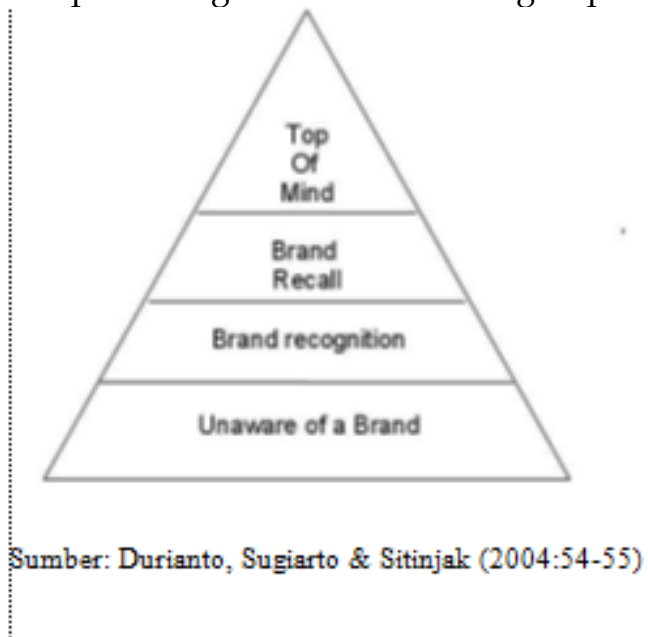

Kemampuan pelanggan untuk mengenali atau mengingat suatu merek produk tergantung pada tingkat komunikasi atatu persepsi pelanggan 
terhadap merek produk yang ditawarkan. Berikut adalah tingkatan dari brand awareness Aaker (1996):

\section{Unaware of brand}

Pada tahapan ini, pelanggan merasa ragu atau belum yakin apakah sudah mengenali merek yang disebutkan atau belum. Pelanggan juga tidak menyadari akan kehadiran merek yang disebutkan.

2. Brand recognition

Pada tahapan ini, pelanggan mampu mengidenti-fikasi merek yang disebutkan. Pelanggan sudah mengenal tetapi masih membutuhkan alat (bantu-an) untuk mengingat merek tersebut. Implikasi dari brand recognition ini menjadi penting ketika seseorang berada pada suatu point of purchase. Untuk meningkatkan brand recognition nama merek haruslah berbeda, khusus, dan tidak biasa.

3. Brand recall

Pada tahapan ini, pelanggan mampu mengingat merek tanpa diberikan stimulus. Pengingatan kembali terhadap merek didasarkan pada per-mintaan seseorang untuk menyebutkan merek tertentu dalam suatu kelas produk. Menurut Keller (2003) untuk meningkatkan brand recall maka nama merek yang dipilih harus:

a. Nama merek sederhana dan mudah untuk diucapkan. Kesederhanaan nama merek dapat mempermudah konsumen dalam memahami nama merek.

b. Kemudahaan untuk diucapkan diperlukan untuk meningkatkan pengulangan secara lisan dalam rangka membangun daya ingat yang kuat. Pengucapan juga mempengaruhi timbul-nya perhatian dan keinginan konsumen menyebutkan nama merek secara lisan.

c. Idealnya nama merek harus jelas dapat dipahami dan tidak memiliki arti yang ambigu.

d. Untuk mempertinggi brand recall nama merek harus terdengar akrab dan memiliki arti.

\section{Top of mind}

Pada tahapan ini, pelanggan mengingat merek sebagai yang pertama kali muncul di pikiran saat berbicara mengenai kategori produk tertentu, berada pada posisi istimewa. Dalam pengertian sederhana, merek tersebut menjadi pimpinan dalam benak konsumen tersebut dibandingkan nama merek-merek lain.

\section{METODOLOGI}

Jenis Penelitian

Jenis Penelitian

Jenis penelitian yang dilakukan adalah penelitian kualitatif. Menurut Sugiyono (2017, hlm.
8) mengatakan bahwa: "Metode penelitian kualitatif sering disebut metode penelitian naturalistik karena penelitiannya dilakukan pada kondisi yang alamiah (natural setting); disebut juga sebagai metode etnographi, karena pada awalnya metode ini lebih banyak digunakan untuk penelitian bidang antropologi budaya; disebut sebagai metode kualitatif, karena data yang terkumpul dan analisisnya lebih bersifat kualitatif". Dalam penelitian ini digunakan pendekatan library research, atau disebut pendekatan kepustakaan, dengan mengumpulkan refrensi sebanyakbanyaknya.

Metode Analisis Data

Penulisan karya tulis ini menggunakan teknik analisis data deskriptif kualitatif. Data -data yang diperoleh dari tinjauan literature, serta berbagai macam refrensi yang didapat melalui website, maka tersusunlah karya tulis ini yang menggambarkan mekanisme proses dan hubungan antara brand awereness terhadap keputusan pembelian .

Operasional Variabel.

1) Brand awereness $(X)$

Brand awereness adalah Kesadaran merek (brand awareness) adalah kesanggupan seorang calon pembeli untuk mengenali atau mengingat kembali bahwa suatu merek merupakan bagian dari kategori produk tertentu (Humdiana, 2005).

2) Keputusan pembelian (Y1)

Menurut Kotler dan Armstrong (2008) keputusan pembelian konsumen adalah membeli merek yang paling disukai, tetapi dua faktor bisa berada antara niat pembelian dan keputusan pembelian.

3) Media Promosi (Y2)

Promosi merupakan salah satu variabel dalam bauran pemasaran yang sangat penting dilaksanakan oleh perusahaan dalam memasarkan produk jasa (Lupiyoadi, 2013). Promosi yang baik adalah yang dapat menarik konsumen sebanyakbanyaknya untuk beralih kepada produk atau jasa yang ditawarkan

Luaran Hasil penelitian.

Berdasarkan dengan kajian yang telah dibahas, maka penulis membuat kerangka pemikiran yang tertuang dalam gambar-gambar seperti berikut :

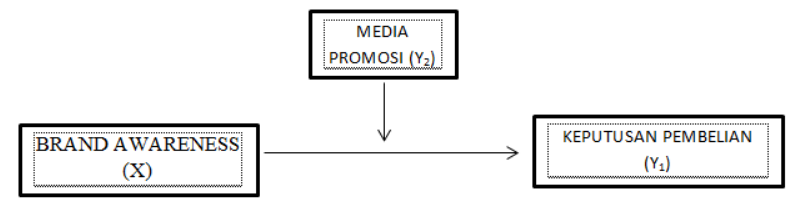




\section{HASIL PENELITIAN DAN PEMBAHASAN}

Brand awereness dapat berpengaruh secara signifikan terhadap keputusan pembelian. Brand awereness merupakan kesadaran akan merek. Merek dapat memberikan manfaat yang besar bagi produsen maupun konsumen. Bagi konsumen merek mampu menambah nilai bagi konsumen. Dimana adanya persepsi dan keyakinan atas produk yang menyebabkan konsumen ingin terasosiasikan dan membelinya, sehingga konsumen tidak segan membayar mahal untuk mendapatkan produk dengan merek tertentu. Konsumen bersedia membayar lebih tinggi suatu produk karena terdapat merek yang merupakan jaminan konsistensi kualitas dan nilai tertentu yang diyakini terkandung didalamnya, tanpa adanya merek konsumen menjadi kurang merasa aman dari kemungkinan buruk diluar harapan. Sebelum konsumen melakukan keputusan pembelian, konsumen harus mengetahui beberapa merek yang terdapat di pasaran. Oleh karena itu konsumen harus mengetahui tentang brand awareness (kesadaran merek). Keputusan pembelian merupakan salah satu bagian dari perilaku konsumen. Di mana, perilaku konsumen merupakan tindakan yang secara langsung terlibat dalam usaha memperoleh, menentukan produk dan jasa, termasuk proses pengambilan keputusan yang mendahului dan mengikuti tindakantindakan tersebut. Menumbuhkan kesadaran merek tidaklah instan, perlu adanya proses yang panjang, salah satu contohnya mulai dari brand recall. Brand recall adalah kemampuan konsumen untuk mengingat merek dari ingatan ketika diberikan kategori produk, kebutuhan terpenuhi oleh kategori, atau pembelian atau penggunaan situasi sebagai petunjuk . selanjutnya Top of mind pada tahapan ini pelanggan mengingat merek sebagai yang pertama kali muncul di pikiran saat berbicara mengenai kategori produk tertentu, berada pada posisi istimewa. Tentunya merek yang melekat pada pikiran konsumen juga dipengaruhi faktor-faktor pendukung contohnya adalah promosi yang dilakukan oleh perusahaan. Promosi merupakan salah satu penentu faktor keberhasilan suatu program pemasaran. Betapapun berkualitasnya suatu produk, bila konsumen belum pernah mendengarnya dan tidak yakin bahwa produk itu tidak akan berguna bagi mereka, maka mereka tidak akan pernah membelinya (Tjiptono,1997). Media promosi yang sering digunakan untuk menyampaikan informasi tentang produk adalah media periklanan. Periklanan merupakan salah satu media yang digunakan perusahaan, bisa diklasifikasikan menurut tujuannya yaitu, untuk memberikan informasi, membujuk dan mengingatkan (Tjiptono, 1997). Inti dari periklanan adalah untuk memasukan sesuatu dalam pikiran konsumen dan mendorong konsumen untuk bertindak atau adanya kegiatan periklanan sering mengakibatkan terjadinya penjualan dengan segera, meskipun banyak juga penjualan terjadi pada waktu mendatang. Dengan demikian, secara umum dapat dikatakan bahwa tujuan periklanan adalah untuk meningkatkan penjualan yang menguntungkan.

\section{DAFTAR PUSTAKA}

Abdul Latief. 2018. ANALISIS PENGARUH PRODUK, HARGA, LOKASI DAN PROMOSI TERHADAP MINAT BELI KONSUMEN PADA WARUNG WEDANG JAHE (STUDI KASUS WARUNG SIDO MAMPIR DI KOTA LANGSA). Jurnal Manajemen Dan Keuangan. Vol. 7, No.1. https://ejurnalunsam.id/index.php/jmk/ar ticle/view/756

Hatane Semuel dan Kelvin Yohanes Setiawan. 2018. PROMOSI MELALUI SOSIAL MEDIA, BRAND AWARENESS, PURCHASE INTENTION PADA PRODUK SEPATU OLAHRAGA. Jurnal Manajemen Pemasaran.Vol.12, No.1. 47-52 http:// jurnal pemasar an.petra.ac.id/index. php/ mar/ article/view/20721

Tjiptono, Fandy. 2006. Pemasaran Jasa. Edisi Pertama. Malang: Bayumedia Pubhlishing.

Harris Kristanto dan Ritzky Karina M.R. Brahmana. 2016.PENGARUH PRODUCT PLACEMENT PADA FILM INDONESIA TERHADAP BRAND AWARENESS DAN PURCHASE INTENTION MASYARAKAT SURABAYA. Jurnal Manajemen Pemasaran. Vol.10, 20-26. http://jurnalpemasaran.petra.ac.id/index.p $\mathrm{hp} / \mathrm{mar} /$ article/view/19770

Nadya Egileona Wibowo. 2017. PENGARUH BRAND AWARENESS TERHADAP KEPUTUSAN PEMBELIAN (STUDI KASUS PADA YELLOW TRUCK CABANG SUNDA BANDUNG TAHUN 2017). e-Proceeding of Applied Science. Vol.3, No.2. Page 230. https://openlibrary.telkomuniversity.ac.id/ pustaka/files/135786/jurnal_eproc/pengaru h-brand-awraeness-terhadap-keputusanpembelian-studi-kasus-yellow-truck-cabangsunda-bandung.pdf.

Sri Rahayusih Wilujeng. 2014. PENGARUH 
Jurnal Studi Manajemen dan Bisnis Vol. 6 (2) 2019: 78-83

BRAND AWARENESS DAN BRAND

TRUST TERHADAP KEPUTUSAN

PEMBELIAN PRODUK ORIFLAME.Vol 2,

No.2.

https://jurnalmahasiswa.unesa.ac.id/index. $\mathrm{php} /$ jptn/article/view/8300/8468

Website :

https://www.hestanto.web.id/brand-awarenesskesadaran-merek/

https://www.ekrut.com/media/brand-awarenessadalah

https://www.tribunnews.com/bisnis/2015/12/10

/pertumbuhan-industri-periklanan-

indonesia-sewindu-terakhir-terhitung-

menakjubkan 